\title{
Kamil Siwek*
}

\section{COMMENTARY (GLOSS) TO THE RESOLUTION OF THE PANEL OF SEVEN JUDGES OF THE SUPREME COURT OF 20 MARCH 2019, I KZP 15/18}

\begin{abstract}
The paper addresses the issue of an extraordinarily lenient penalty for crimes threatened with mandatory cumulative penalties of deprivation of liberty and fines. It was established that Article $60 \S 6$, point 2 of the Criminal Code clearly resolves this issue in a positive way and provides for imposing only the penalty of deprivation of liberty as an exceptionally lenient penalty. Thus, the author questioned the assertion that the extraordinary leniency in respect of the cumulative sanctions of imprisonment consists in the meting out of a sentence of imprisonment not less than one third of the lower limit of the statutory penalty and a fine pursuant to general principles.
\end{abstract}

Keywords: extraordinary leniency, cumulative fine, extraordinary punishment, counteracting drug addiction, crime

First, a bit of history, which is useful in interpreting the present legislation. As is known in the first Polish Penal Code of 1932, the method of extraordinary leniency was regulated by art. $59 \S 1$ points a-d. Instead of detention for up to 5 years,

* Kamil Siwek, MSc, Faculty of Law and Administration of the Adam Mickiewicz University in Poznań, e-mail address: kamil.siwek@amu.edu.pl. ORCID: 0000-0001-6901-0061.

1 OSNKW 2019, No. 4, item 20. 
the court could impose a fine from 5 to 200000 PLN (in the original wording of art. $42 \S 1$ ). Instead of imprisonment of more than 5 years (art. $59 \S 1$, point $\mathrm{b}$ or up to 5 years (art. $59 \S 1$, point $\mathrm{c}$ ), detention could not be used if the offence was based on low motives (art. $59 \S 2$ ). ${ }^{2}$ In many cases, particularly for property offences, such inclusion has prevented the application of extraordinary leniency. ${ }^{3}$ Thus, it was not a successful regulation, and, therefore, in the postwar period it met with almost widespread criticism within the science of criminal law. Indeed, it was described as "flawed, unclear and in need of a prompt amendment." ${ }^{4}$ The fact that the fine was not subject to extraordinary leniency deserves special attention. ${ }^{5}$

As is known, also against the background of the Penal Code of 1969, the dominant case law of the Supreme Court assumed that the fine was not subject to extraordinary leniency (both spontaneous and cumulative). This was the main argument in favour of the well-known resolution of a panel of seven judges of the Supreme Court of 16.12.1971, VI KZP 7/71. ${ }^{6}$ The problem resolved by the Supreme Court appeared against the background of art. 3, point 1 of the Act of 22 April 1959 on Fighting with illegal spirits. ${ }^{7}$ This position was then repeated by the Supreme Court in subsequent judgments. It was reminded in the voted resolution. All these judgments strongly emphasised that the Code's rules on extraordinary leniency apply only to imprisonment and not to fines.

2 See: Wolter, W., Zarys systemu prawa karnego. Część ogólna, Vol. II, Kraków 1934, pp. 96-97.

3 See: Śliwiński, S., Polskie prawo karne materialne. Czesść ogólna, Warszawa 1946, p. 475 .

4 Ibidem; additionally Bafia, J., Odpowiedzialność karna za przestęstwa przeciwko własności społecznej, Warszawa 1960, p. 43; Andrejew, I., in: Andrejew, I., Świda W., Wolter, W. (eds.), Kodeks karny z komentarzem, Warszawa 1973, p. 241; Judgment of the Supreme Court of 2.09.1958, II K 793/58, OSPiKA 1959, No. 6, item 170.

5 See: Siewierski, M., Kodeks karny i prawo o wykroczeniach. Komentarz, Warszawa 1965, p. 111 (thesis 3); and the Supreme Court judgment given there (published "OSNKW 25/65"). That is the judgment of the Supreme Court of 4.12.1961, II K 863/61, OSNKW 1963, No. 2, item 25 - the same as recalled in the resolution voted on.

6 LEX No. 20842.

7 Dz. U. (Journal of Laws) No. 27, item 169. In the criminal law literature such a solution has found both its supporters and opponents. See: in particular Daszkiewicz, K., Nadzwyczajne złagodzenie kary w polskim kodeksie karnym, Warszawa 1976, pp. 147-157; Raglewski, J., Model nadzwyczajnego złagodzenia kary $w$ polskim systemie prawa karnego (Analiza dogmatyczna w ujęciu materialnoprawnym), Kraków 2008, pp. 382-386. 
It should be noted, however, that this was not a uniform line of jurisprudence when it comes to determining which basic or additional penalty was subject to extraordinary leniency. The decision of the panel of seven judges of the Supreme Court of 3 February 1951, II K 1216/50 $0^{8}$ explicitly allows for the possibility of not adjudicating the mandatory confiscation of all property provided for in art. 7(b) of the Decree of 31 August 1944 on the punishment of fascist-Hitlerite criminals guilty of murder and ill-treatment of the civilian population and of prisoners of war, and the punishment of traitors to the Polish Nation, ${ }^{9}$ threatening cumulatively with the death penalty for the crime specified in art. 1 of this Decree. The Supreme Court assumed that "if the court, under the provisions of the law (art. 5 of the Decree) has the power to lenient the most severe penalty - the death penalty (art. 1 of the Decree), it must be presumed that it was the legislator's intention that the power granted to the court should also include the leniency of penalties on property (...)."

As can be seen, no specific legal basis was sought for the possibility of waiving the mandatory cumulative confiscation of all property when the court applied extraordinary leniency. It should also be noted that the Supreme Court did not invoke the fact that the confiscation of property is not subject to extraordinary leniency under art. 59 of the Criminal Code of 1932 (since the confiscation of property was not known to the Code, the rules of extraordinary leniency could not apply to it either ${ }^{10}$ ). Simply referred to the well-known a maiore ad minus conclusion ("who can do the greater can certainly do the lesser"). However, it was not referred to in those Supreme Court judgments (recalled by the Supreme Court in its voted resolution), in which, against the background of various legal solutions, the admissibility of an extraordinary leniency of a cumulative fine was consistently denied. From this point of view, the accuracy of these judicature's statements can be questioned. Indeed, if the Criminal Code of 1969 allowed for extraordinary leniency of imprisonment, then it also allowed for extraordinary leniency of fines. It is particularly noteworthy that the above-mentioned judgment of the Supreme Court of 3 February 1951 did not used the argument that the crime under art. 1 point 1 of the August Decree is characterised by a high

\footnotetext{
$8 \quad$ LEX No. 161234.

9 Consolidated text: Dz. U. (Journal of Laws) of 1946, No. 69, item 377.

10 After all, the additional punishment of the confiscation of all the convicted person's property was a complete novum in Polish criminal law. See: Kubicki, L., Zbrodnie wojenne $w$ świetle prawa polskiego, Warszawa 1963, p. 176.
} 
degree of social noxiousness (it is difficult to find an example of a more social noxiousness act than the crime under Article 1 item 1 of the August Decree ${ }^{11}$ ), and that the Court when allowing the extraordinary leniency of confiscation of property, connected to the death penalty, will lead to a specific preference for the perpetrators of such crimes over the perpetrators of crimes for which there is no risk of the mandatory confiscation of all property (that is to say, the court applying extraordinary leniency will treat both cases equally ${ }^{12}$ ). Moreover, neither the argument that extraordinary leniency of property confiscation would go against the legislator's intention as expressed in the cumulative sanction, nor the argument that extraordinary leniency is an exceptional situation and, as such, is not subject to a broadening interpretation (it involves the application of the exceptiones non sunt extendendae rule) have been addressed. Rather, it has simply taken a judgment that was fully based on the rules of the universally accepted legal inference (a fortiori). It is clear that this kind of inference has nothing to do with a broadening interpretation. ${ }^{13}$

It should only be added here that the principle set out in the judgment of 3 February 1951, that the extraordinary leniency of the death penalty also consists in waiving the mandatory confiscation of property, was also extended by the Supreme Court to include sentences of timely imprisonment for the crimes referred to in articles 2, 3 and 4 of the said Decree. ${ }^{14}$ This is noteworthy because it was a radical change in the case-law of the Supreme Court in this area, as the

11 The exceptionally high degree of social noxiousness of all acts covered by the August Decree was unequivocally stressed in the literature. See: Kubicki, L., op. cit., p. 176.

12 It should be noted that this is the direction in which Z. Ćwiąkalski's main argumentation goes in: Wróbel, W., Zoll, A. (eds.), Kodeks karny. Czesść ogólna, vol. I, komentarz do Art. 53-116, Warszawa 2016, p. 174. Of course, this circumstance may lead to doubts as to the appropriateness of the admissibility of an extraordinary leniency of the cumulative fine de lege ferenda, but it cannot be an argument in favour of its inadmissibility de lege lata.

13 M. Cieślak gave warning that the question of whether extraordinary leniency is certainly an exceptional situation and the provisions expressing it are exceptional seems quite legitimate. It can be argued, after all, that the rule is rather the freedom of the individual, and the criminal prohibition and punishment is the exception to this freedom. Thus, extraordinary leniency, which mitigates the exceptional criminal responsibility of certain behaviour, is to some extent a return to the rule. In short, it is the provisions introducing criminal responsibility that constitute exceptions to the higher non-punishment rule, so that provisions, even if they reduce such criminal responsibility, are not exceptional. This is against the danger of mistakenly recognising a certain provision as exceptional in the context of the prohibition of broadening interpretation of exceptional provisions - Cieślak, M., Polskie prawo karne. Zarys systemowego ujęcia, Warszawa 1996, p. 95.

14 See: Kubicki, L., op. cit., pp. 178-179. 
Supreme Court had previously assumed on several occasions that the confiscation of all the convicted person's property was mandatory even when the court applied extraordinary leniency under art. 5 of the Decree. ${ }^{15}$ Since this direction of interpretation referred to the additional penalty, the confiscation of property, and thus - by analogy with a fine - of a property penal measure, it should be treated as an important reference in considerations on the shape of the penalty for crimes mitigated by obligatory cumulative fines. ${ }^{16}$

The most important thing is that with the entry into force of the Criminal Code of 1997 providing for extraordinary leniency of "every penalty" 17 and thus also fines, the rules on extraordinary leniency have changed radically. For this reason, the statements of the Supreme Court, broadly referred to in the voted resolution that had been clarified under the previous criminal codes and which generally rejected the admissibility of extraordinary leniency of cumulative fines (de lege lata), have completely lost their validity. This is because they were formed under different legal conditions, i.e. when the fine was generally not subject to extraordinary leniency. Therefore, these statements cannot support the interpretation specified in the voted resolution.

It turns out that the thesis expressed in the voted resolution that "the institution of extraordinary leniency was shaped in the Criminal Code of 1997 in a similar way as in the Codes of 1932 and 1969" deviates from the truth. The point is that, from the point of view of the admissibility of extraordinary leniency, the institution of extraordinary leniency in the 1997 Criminal Code, as compared to the 1932 and 1969 Criminal Codes, has been shaped differently. It is necessary to stop here for a while when emphasizing the most important issues.

Firstly, in Article $60 \S 6$ point 2 of the Criminal Code, the Act operates with the term "if the act constitutes another crime." Since the general term "another crime" is used here, so the normative rationale (lege non distinquente) clearly indicates that the solution provided for in art. $60 \S 2$ of the Criminal Code

15 See: Pasek, A., Przestęstwa okupacyjne w polskim prawie karnym z lat 1944-1956, Wrocław 2002, pp. 163-164, note 571 and the case law cited there.

16 An important remark: it is sometimes claimed that art. $60 \S 6$ point 1 of the Criminal Code is an "empty regulation", because in the current state of law there is supposedly no crime punishable by a minimum of 25 years' imprisonment. See: Kulik, M., in: Mozgawa, M. (ed.), Kodeks karny. Komentarz, Warszawa 2017, p. 227. It's hard to agree with this position. After all, it is obvious that art. 1 point 1 of the Decree is in force - and precisely to the crime specified in this article the mechanism of extraordinary leniency specified in art. $60 \S 6$ point 1 of the Criminal Code may apply.

17 See: Góral, R., Kodeks karny. Praktyczny komentarz, Warszawa 2007, p. 127. 
has been broadly defined by the legislature and generally also includes crimes threatened with an obligatory cumulative fine. This is also indicated, without any doubt, by the logical rationale behind the logical division. The point is that the provision of art. $60 \S 6$ of the Criminal Code reflects all types of statutory threats occurring in the Polish legislation, including those arising in non-codex acts providing for criminal liability. This is reliably due to the requirement of the adequacy of logical division. ${ }^{18}$ Otherwise, it should be considered that the legislator is not a rational legislator and has insufficient knowledge in the field of logic, ${ }^{19}$ because in the logical division created by him, whose normative reflection is the provisions of art. $60 \S 6-7$ of the Criminal Code, he completely omitted the types of prohibited acts threatened with obligatory cumulative sanctions. ${ }^{20}$ Rejecting a limine such unacceptable reasoning, it should be assumed that the solution provided for in art. $60 \S 6$ point 2 of the Criminal Code also applies to crimes threatened with obligatory cumulative fines. Therefore, there is not any lack of regulations in this Act. ${ }^{21}$ Different statements, referring to the fact that in the case of granting extraordinary leniency, the "difference between the crimes differentiated by the number of obligatory sanctions" is obliterated or that "art. $60 \S 6$ of the Criminal Code sets out the rules for leniency," boil down exclusively to challenging the clear decision of the legislator, who decided in art. $60 \S 6$ point 2 of the Criminal Code that the rules of extraordinary leniency also apply to obligatory cumulative sanctions. Therefore, additional precision

18 See: Siwek, K., Nadzwyczajne złagodzenie grzywny kumulatywnej, "Czasopismo Prawa Karnego i Nauk Penalnych", 2018, No. 4, pp. 7-20. Following the work given, it should be briefly repeated that points $1-2 \S 6$ of art. 60 of the Criminal Code apply to all crimes of any form of criminal threat. This case was similarly solved in art. $101 \S 1$ points $1-2$ of the Criminal Code. This is what the logical division is all about, including the use of the term "another crime". As it is known, the term "another" expresses the completion of the separated parts of the division, which reliably provides the exhaustive character of logical division. See: Ziembiński, Z., Logika praktyczna, Warszawa 1995, p. 59. Therefore, art. $60 \S 6$ point 2 of the Criminal Code refers to all crimes not threatened with a minimum penalty of 25 years of imprisonment, while art. $101 \S$ 1 point 2 of the Criminal Code refers to all crimes remaining after the exclusion of the crime of murder.

19 More information on rational and intellectual assumptions, including the legislator's best knowledge of logic can be found in: Zieliński, M., Wykładnia prawa. Zasady-reguly-wskazówki, Warszawa 2017, pp. 260-261, p. 266.

20 It would not be a logical division at all, because an incorrect logical division is not a logical division. See: Siwek, K., op. cit., p. 9, and the literature given there.

21 The issue of the admissibility of an extraordinary leniency of cumulative fine is positively resolved in the Act. It is understandable that not everything in the Act must be clearly (explicitly) stated. It is in such cases that the rules of a fortiori are applied. There is nothing special about this. 
in the Act of the method of extraordinary leniency of a cumulative fine would be a legislative "over-feeding" by the legislator.

Secondly, it cannot be disputed that when the Criminal Code, in addition to the optional basis for extraordinary leniency, provides for the possibility to waive the penalty (e.g. art. $22 \S 2$ of the Criminal Code), such waiver is of a full nature, as it always applies to the entire penalty - including the obligatory cumulative fine. By reasoning a fortiori (arg. a maiori ad minus), it should be inferred that the extraordinary leniency of a cumulative fine in these cases results from the Act more strongly than an exemption from it. ${ }^{22}$ It would be grossly inconsistent to assume that the waiver (more) also applies to the cumulative fine, while the extraordinary leniency (less) is to be applied without it and only to the imprisonment.

Thirdly, the Supreme Court is obviously right when it emphasises that the principles of extraordinary leniency provided for in art. $60 \S 1-7$ of the Criminal Code are not specified in art. $38 \S 1-3$ of this Code. After all, these provisions concern the extraordinary aggravation of the penalty or the extraordinary reduction of the upper limit of the statutory threat, and not the lower limit, as is the case with extraordinary leniency. However, it is not at all certain whether the said rules are not also contained in art. 59 or 61 of the Criminal Code. After all, it is obvious that when the law allows for a waiver, it allows for extraordinary leniency too. ${ }^{23}$ From a practical point of view, this is very important. For if in relation to the perpetrator defined in art. $60 \S 3$ of the Criminal Code the court may refrain from imposing the penalty under the general art. $61 \S 1$ of the Criminal Code, then it may also extraordinary lenient the penalty (arg. a maiori ad minus). ${ }^{24}$ In any event, a firm determination that there has been a normative exclusion of the admissibility of extraordinary leniency of a cumulative fine requires a careful analysis of all

22 It is important to note that the whole group of provisions of the general part of the Criminal Code providing the possibility to waive the penalty (art. $14 \S 2,22 \S 2,25 \S 2$ and $26 \S 3$ ) may be applicable to all types of offenses under penalty, including the most serious crimes and murders, therefore they are not limited (like in art. 59 of the Criminal Code) to minor offences only. It is difficult to suppose that the legislator's view on this matter would be diametrically opposed to the view on act of illegally processing poppy straw for personal gain.

23 See: Makarewicz, J., Kodeks karny z komentarzem, Lwów 1935, p. 167; Śliwiński, S., op. cit., p. 475. Opposite point of view - Wolter, W., op. cit., p. 95.

24 It should be emphasized that pursuant to art. $61 \S 2$ of the Criminal Code, a withdrawal from imposing a penalty on the offender specified in art. $60 \S 3$ of the Criminal Code consists in total withdrawal from applying criminal consequences. See: Marek, A., Kodeks, p. 207. Therefore, there is no doubt that art. $61 \S 2$ of the Criminal Code is the basis for waiving the cumulative fine. 
criminal law solutions, in particular those providing for the possibility of immunity from fines, because the law "must be interpreted on the basis of the whole text of the issued and non-repealed provisions. ${ }^{" 25}$ Therefore, the manner of interpretation and application of the provision of Article $60 \S 6$ point 2 of the Criminal Code is co-decided by the implications of the solution provided for in art. 61 of the Criminal Code, which immanently also includes extraordinary leniency.

Fourthly, since the a fortiori rules are based on the assumption of the consequences of the legislator's preferences and assessments, ${ }^{26}$ it can no longer be justifiably claimed (referring in the sphere of interpretation and application of art. $60 \S 6$ point 2 of the Criminal Code to the a maiori ad minus reasoning and assuming that since the court may extraordinarily lenient the penalty of imprisonment, it may also extraordinarily lenient the cumulative fine) that the admissibility of an extraordinary leniency of the cumulative fine would "undermine the aim of the legislator as expressed in the cumulative fine." Such an argument in fact amounts to a negation of an explicit decision by the legislator. Of course, the reference to a maiori ad minus argumentation in this respect does not mean that the linguistically unambiguous provision conferring competence is broken, since it is a consistent conclusion and adds nothing new to the content of the legal rule. ${ }^{27}$

Fifthly, the Supreme Court's assertion in the resolution voted on that "the elimination of an obligatory sanction for a crime must have the clear statutory mandate" present the whole problem from the wrong side. The answer was requested not by the question whether the Criminal Code allows for a waiver of an obligatory cumulative fine in such situations in which the court applies extraordinary leniency, but by the question whether the court was equipped with the power to impose such a fine at that time (i.e. that it was necessary to demonstrate the power to impose a fine). The answer to this question must be negative. As we know, the extraordinary size of the sentence, and thus the extraordinary leniency, leads to a "modification of the criminal penalty." 28

25 See: Ziembiński, Z., Problemy podstawowe prawoznawstwa, Warszawa 1980, p. 289.

26 See: Jabłońska-Bonca, J., Wstęp do nauk prawnych, Poznań 1994, p. 118; Ziembiński, Z., Logika, p. 251-253.

27 The a fortiori conclusion is the consequence of a standard being a part of the legal system and binding as the standards directly established by the legislator. See: Wróblewski, J., Wstęp do nauki o państwie i prawie. Część II. Mechanizm działania prawa, in: Ehrlich, S. (ed.), Warszawa 1962, pp. 111-112.

28 See: Marek, A., Prawo karne, Warszawa 2011, p. 348. 
Against this background it should be stressed that the method of extraordinary leniency described in the Criminal Code (at the normative level of reading the legal text) modifies (absorbs) the sanction (the shape of the statutory threat of penalty) without, however, changing this statutory threat (only at the descriptive level of reading the legal text) in an independent and autonomous way, shaping only new (milder) limits of the statutory threat (thus, it contains elements modifying the sanctioning standard). ${ }^{29}$ It is obvious that the classification provision is always an incomplete central provision, the content of which is affected by other provisions (modifiers) contained mainly in the general part of the Criminal Code, including art. $60 \S 6$ of this Code. ${ }^{30}$ In short, when a court applies extraordinary leniency, it is unfailingly incapable of ruling all the criminal measures provided for under the threat of the classification provision. In such a case, the court has at its disposal only penal means provided for in the provisions of art. $60 \S 6-7$ of the Criminal Code. This applies equally to situations in which the court applies an extraordinary leniency of an obligatory or of an optional nature.

Consequently, if a court applies extraordinary leniency, then there are no longer general rules on the assessment of a cumulative fine. ${ }^{31}$ These rules are abolished by the code for the setting of extraordinary leniency. This is determined by the fact that in such situations the entire penalty is subject to extraordinary leniency and only the imprisonment provided for in art. 32 point 3 of the Criminal Code may be imposed under extraordinary leniency. This penalty consumes the entire statutory threat. ${ }^{32}$

29 The literature on criminal law has a different understanding of the content and scope of the terms "statutory threat" and "statutory penalty", sometimes dividing the latter into so-called general statutory penalty and specific statutory penalty. See: Raglewski, J., op. cit., pp. 39-44. However, these are old views, not taking into account the achievements of the modern science of legal interpretation, where a clear distinction is made between two levels of reading the legal text (descriptive and directive). From this point of view, neither the traditional understanding of the term "statutory threat" (as including only the threat in the classification provision. See: Stefanska, B. J., Kara pozbawienia wolności do 20 lat, "Prokuratura i Prawo" 2018, No. 5, pp. 33-35 and the statements of the judiciary and the literature cited therein) nor the distinction between "statutory penalty", including "general statutory penalty" and "specific statutory penalty", are valid today.

30 As we know, "the provisions formulated in the general part of the act are an editorial supplement to all the specific provisions of a given act, if it is not reserved otherwise". See: Ziembiński, Z., Problemy podstawowe..., p. 289.

31 Opposite point of view - the judgment of the Court of Appeal of Lublin of 23.03.2003, II AKa 286/06, LEX No. 183571 and the Supreme Court in the main thesis of the voted resolution.

32 See: Raglewski, J., op. cit., pp. 387-388. 
Sixthly, in the final part of the justification of the voted resolution, the Supreme Court emphasises that although the present case is an example of the application of art. 116 of the Criminal Code, the cumulative sanction does not reflect the legislator's preference, defined in art. 32 points $1-3$ of the Criminal Code, in the choice of the type of penalty by the judge, since in these cases the accumulation of penalties simply excludes the choice. This is a completely wrong approach. The point is that the whole of art. 32 of the Criminal Code concerns only the ordinary penalty. That this is the case is confirmed by the fact that art. 32 points $4-5$ of the Criminal Code contains the two most severe penalties, 25 years imprisonment and life imprisonment, which can never be imposed under the extraordinarily lenient penalty. ${ }^{33}$ In short, art. 32 of the Criminal Code is not a provision from the sphere of extraordinary punishment. It should be emphasized that art. $60 \S 6$ of the Criminal Code expresses, independently and exhaustively, preferences when choosing the type of penalty imposed under extraordinary leniency and in this respect art. 32 of the Criminal Code is not applicable (art. $60 \S 6$ of the Criminal Code constitutes a lex specialis in relation to art. 32 of the Criminal Code). This preference, expressed by the legislator, for the choice of the type of penalty, is clearly (explicitly) reflected in the provisions defining extraordinary leniency for crimes, and reflects the system of penalties specified in art. 32 of the Criminal Code (from the most lenient - to the most severe).

Moreover, it should be clearly stated that art. 32 of the Criminal Code is only a reflection of the overriding principle of punishment, taking into account the principles of humanitarianism (art. 3 of the Criminal Code). ${ }^{34}$ Because art. 3 of

33 The most severe penalty already extraordinarily lenient in accordance with art. $60 \S 6$ point 1 of the Criminal Code is the penalty of imprisonment from 8 to 15 years, also with respect to the act under art. 1 point 1 of the already cited August Decree. See: Hałas, R., in: Grześkowiak, A., Hałas, R. (eds.), Kodeks karny. Komentarz, Warszawa 2015, p. 460. See also: Zgoliński, I., in: Konarska-Wrzosek, V. (ed.), Kodeks karny. Komentarz, Warszawa 2016, p. 373.

34 The principle contained in art. 3 of the Criminal Code should be treated "as the main principle of the application of criminal law sanctions". See: Trafny, M., Zasada humanitaryzmu w kodeksie karnym, "Prokuratura i Prawo", 2007, No. 3, p. 32. It is from art. 3 of the Criminal Code "the primacy of imprisonment penalty arises". See: Kunicka-Michalska, B., in: Rejman, G. (ed.), Kodeks karny. Część ogólna. Komentarz, Warszawa 1999, p. 209. Therefore, the literature on the subject emphasizes that the construction of art. 32 of the Criminal Code proves its compliance with art. 3 of this Code. See: Sienkiewicz, Z., in: Bojarski, M. (ed.), Prawo karne materialne. Część ogólna i szczególna, Warszawa 2015, p. 287. 
the Criminal Code constitutes not only the fundamental principle of the penalty, ${ }^{35}$ but also plays a role in the interpretation of the provisions of criminal law, ${ }^{36}$ this provision should have been taken into account when deciding the present case. However, this issue escaped the attention of the Supreme Court. ${ }^{37}$

In short, the normative content included in art. 32 of the Criminal Code results directly from art. 3 of the Criminal Code, also with regard to the level of the extraordinarily leniency of the penalty. ${ }^{38}$ After all, there is no doubt that "the provision of art. 3 of the Criminal Code applies to the choice of penalties". ${ }^{39}$ Therefore, "the entire Criminal Code as an ordinary law is based on the assumption of respect for the principle of humanity. Thus, the obligatory nature of a specific penalty does not by itself abolish the possibility to choose the type of penalty within the meaning of art. 32 of the Criminal Code, as this possibility is guaranteed in the first place by the overriding conventional and constitutional norms and art. 3 of the Criminal Code that serves as a general principle of criminal law of a directive nature. Therefore, there are no grounds for the thesis that the extra-codex acts which provide for cumulative sanctions for prohibited acts do not pursue the objective resulting from art. 32 points $1-3$ of the Criminal Code".

Seventhly, it is a truism to say that certain circumstances in concreto may argue not only for extraordinary leniency, but also for a particularly low level of the extraordinary leniency. After all, it cannot be absolutely ruled out that the imposition of imprisonment within the limits set by art. $60 \S 6$ point 2 of the Criminal Code and a fine on general principles will nonetheless lead to the level of punishment exceeding the established degree of guilt. This will particularly

35 See: Warylewski, J., Prawo karne. Czesść ogólna, Warszawa 2017, p. 620. The author rightly emphasises that art. 3 of the Criminal Code includes the principle and not the directive of the penalty. See also Lachowski, J., Marek, A., Prawo karne. Zarys problematyki, Warszawa 2018, p. 277-278; Królikowski, M., Zawłocki, R., Prawo karne, Warszawa 2015, p. 396.

36 See Wąsek, A., Kodeks karny. Komentarz, vol. I, Gdańsk 1999, p. 51.

37 Attention to the link between the solution provided for in art. 3 of the Criminal Code and the grounds for extraordinary leniency specified in art. $60 \S 2$ of the said Code we owe to Wąsek, A., op. cit., pp. 52-53.

38 On the application of art. 3 of the Criminal Code in the sphere of extra-codex criminal law. See: Zalewski, W., in: Królikowski, M., Zawłocki, R. (eds.), Kodeks karny. Część ogólna. Komentarz, Warszawa 2017, pp. 172-173. In the literature it has been emphasized that the exclusion of the application of art. 3 of the Criminal Code by a special law "is not probable". Kunicka-Michalska B., in: Kodeks karny, p. 203. 2017, p. 33.

39 See: Kozłowska-Kalisz, P., in: Mozgawa, M. (ed.), Kodeks karny. Komentarz, Warszawa 
be the case where there are multiple grounds for extraordinary leniency. Therefore, the judge must have a wide range of possibilities to determine the level of extraordinary leniency, including the possibility not to impose a cumulative fine.

Finally, it should be stressed that under art. $60 \S 5$ of the Criminal Code, only an exceptionally lenient penalty of imprisonment (only such a penalty is mentioned in the provision) is subject to conditional suspension. It follows from this that a cumulative fine, imposed on general principles, is not subject to conditional suspension and must be executed. And since the cumulative fine, citing only the example of the penal regulation referred to by the Supreme Court in the final fragment of the justification of the resolution (art. 171 section 1-3 of the Act of 29 August 1997 on Banking Law ${ }^{40}$ ), may reach as much as 10 million PLN, such a perspective will not inspire the perpetrator to cooperate with the law enforcement agency too much. ${ }^{41}$ From this point of view, it is feared that the resolution voted on may lead to a serious limitation of the application of art. $60 \S$ 3-4 of the Criminal Code in matters of organised financial crime.

Therefore, the position should be maintained ${ }^{42}$ that in the light of art. $60 \S$ 6 point 2 of the Criminal Code, extraordinary leniency for a crime cumulatively threatened with imprisonment and a fine consists only in serving the penalty of imprisonment below the lower limit of the statutory threat, but not lower than one third of the limit. The above rule should be extended to all offences. In this matter there is no dilemma of the kind of either extraordinary leniency exclusively for imprisonment and the imposition of a fine on general principles in addition to the imprisonment, or the inability to apply extraordinary leniency at all. ${ }^{43}$ This approach amounts to creating a false alternative as there is a third option consisting in extraordinary leniency also for the cumulative fine.

40 Consolidated text: Dz. U. (Journal of Laws) of 2018, item 2187, as amended.

${ }^{41}$ After all, it should be borne in mind that a fine of this amount is almost ten times the fine that the court may impose under art. $71 \S 1$ of the Criminal Code when it conditionally suspends the execution of the sentence of imprisonment under art. $60 \S 5$ of this Code (PLN 1080 000). For the perpetrator, it certainly makes a difference whether a fine of just over a million PLN or ten million PLN can be imposed on him.

42 See: Siwek, K., Nadzwyczajne złagodzenie, p. 20.

43 See: Ćwiąkalski, Z., Nadzwyczajne złagodzenie kary w praktyce sądowej, Warszawa 1982, p. 161. 


\section{Literature}

Andrejew, I., Świda, W., Wolter, W., Kodeks karny z komentarzem, Warszawa 1973.

Bafia, J., Odpowiedzialność karna za przestępstwa przeciwko własności społecznej, Warszawa 1960.

Cieślak, M., Polskie prawo karne. Zarys systemowego ujęcia, Warszawa 1996.

Ćwiąkalski, Z., Nadzwyczajne złagodzenie kary w praktyce sądowej, Warszawa 1982.

Ćwiąkalski, Z., Kodeks karny. Część ogólna, vol. I, komentarz do Art. 53-116, in: Wróbel, W., Zoll, A. (eds.), Warszawa 2016.

Daszkiewicz, K., Nadzwyczajne złagodzenie kary w polskim kodeksie karnym, Warszawa 1976.

Góral, R., Kodeks karny. Praktyczny komentarz, Warszawa 2007.

Hałas, R., Kodeks karny. Komentarz, Grześkowiak, A., Hałas, R. (eds.), Warszawa 2015. Jabłońska-Bonca, J., Wstęp do nauk prawnych, Poznań 1994.

Królikowski, M., Zawłocki, R., Prawo karne, Warszawa 2015.

Kubicki, L., Zbrodnie wojenne w świetle prawa polskiego, Warszawa 1963.

Kulik, M., Kodeks karny. Komentarz, Mozgawa, M. (ed.), Warszawa 2017.

Kunicka-Michalska, B., Kodeks karny. Czesść ogólna. Komentarz, Rejman, G. (ed.), Warszawa 1999.

Lachowski, J., Marek A., Prawo karne. Zarys problematyki, Warszawa 2018.

Makarewicz, J., Kodeks karny z komentarzem, Lwów 1935.

Marek, A., Prawo karne, Warszawa 2011.

Pasek, A., Przestępstwa okupacyjne w polskim prawie karnym z lat 1944-1956, Wrocław 2002.

Raglewski, J., Model nadzwyczajnego złagodzenia kary w polskim systemie prawa karnego (Analiza dogmatyczna w ujęciu materialnoprawnym), Kraków 2008.

Sienkiewicz, Z., Prawo karne materialne. Część ogólna i szczególna, Bojarski, M. (ed.), Warszawa 2015.

Siewierski, M., Kodeks karny i prawo o wykroczeniach. Komentarz, Warszawa 1965.

Siwek, K., Nadzwyczajne złagodzenie grzywny kumulatywnej, “Czasopismo Prawa Karnego i Nauk Penalnych", 2018, Vol. 4.

Stefańska, B.J., Kara pozbawienia wolności do 20 lat, "Prokuratura i Prawo" 2018, No. 5.

Śliwiński, S., Polskie prawo karne materialne. Część ogólna, Warszawa 1946.

Warylewski, J., Prawo karne. Czesść ogólna, Warszawa 2017.

Wąsek, A., Kodeks karny. Komentarz, vol. I, Gdańsk 1999. 
Wolter, W., Zarys systemu prawa karnego. Część ogólna, vol. II, Kraków 1934.

Wróblewski, J., Wstęp do nauki o państwie i prawie. Część II. Mechanizm działania prawa, Ehrlich, S. (ed.), Warszawa 1962.

Zalewski, W., Kodeks karny. Część ogólna. Komentarz, Królikowski, M., Zawłocki, R. (eds.), Warszawa 2017.

Zgoliński, I., Kodeks karny. Komentarz, Konarska-Wrzosek, V. (ed.), Warszawa 2016.

Zieliński, M., Wykładnia prawa. Zasady - reguły - wskazówki, Warszawa 2017.

Ziembiński, Z., Problemy podstawowe prawoznawstwa, Warszawa 1980.

Ziembiński, Z., Logika praktyczna, Warszawa 1995.

\section{Legislation}

Act of 22 April 1959 on Fighting with illegal spirits, Dz.U. (Journal of Laws) No. 27, item 169.

Act of 29 August 1997 on Banking Law, consolidated text: Dz.U. (Journal of Laws) of 2018, item 2187, as amended.

Decree of 31 August 1944 on the punishment of fascist-Hitlerite criminals guilty of murder and ill-treatment of the civilian population and of prisoners of war, and the punishment of traitors to the Polish Nation, consolidated text: Dz.U. (Journal of Laws) of 1946 No. 69, item 377.

\section{Judicial decisions}

Judgment of the Supreme Court of 2.09.1958, II K 793/58, OSPiKA 1959, No. 6, item 170.

Judgment of the Supreme Court of 4.12.1961, II K 863/61, OSNKW 1963, No. 2, item 25. Judgment of the Administrative Court in Lublin of 23.03.2003, II Aka 286/06, LEX No. 183571. 